\title{
IMPROVING EFL LEARNERS' SPEAKING SKILL THROUGH THE USE OF CODE SWITCHING STRATEGIES IN THE CONVERSATION
}

\author{
Syamsudin \\ (syamsudinuin@yahoo.com)
}

Department of English Letters, Faculty of Humanities

Universitas Islam Negeri Maulana Malik Ibrahim Malang

\begin{tabular}{ll}
\hline ARTICLE & ABSTRACT \\
\hline Keywords: & $\begin{array}{l}\text { This study is about code switching strategies usage as a part of } \\
\text { communication strategies used by the EFL learners in Higher } \\
\text { Education to improve their speaking skill. This paper presents the } \\
\text { discussion on code switching strategies usage employed by two EFL } \\
\text { strategies, }\end{array}$ \\
$\begin{array}{l}\text { learners to improve their speaking skill. This topic is interesting to be } \\
\text { discussed because the employment of code switching strategies during } \\
\text { communication } \\
\text { the conversation might facilitate EFL learners to learn speaking. This } \\
\text { happens due to the opportunity of the EFL learners to use L1 to express } \\
\text { learning }\end{array}$ & $\begin{array}{l}\text { some unfamiliar vocabularies during the conversation. Further, by } \\
\text { employing code switching strategies in conversation learners might } \\
\text { feel comfortable so that they have courage and self confidence to } \\
\text { practice speaking. Thus, it is crucial for the EFL learners to use code } \\
\text { switching strategies in the process of learning speaking so that they } \\
\text { might improve their speaking ability. }\end{array}$ \\
\hline
\end{tabular}

\section{INTRODUCTION}

Speaking is a very important skill that learners should master in language learning. By mastering speaking learners might put across their thoughts to the interlocutors well. Nevertheless, in reality there are many learners who have learned English for years are still feel difficult to master speaking. Commonly students are difficult to master speaking due to their shortage of linguistic elements such as having little understanding about vocabularies or grammar mastery. According to Bialystok (1990) learners' shortage on linguistic elements might cause gaps of knowledge on second language and in speaking these gaps might influence fluency. In addition, learners' difficulties in speaking are caused by the fact that learners have to focus on forms and function of the language (Brown, 2007). And for many cases, focusing on forms and contents for EFL learners in learning speaking is still difficult if they only understand a few vocabularies. 
JEASP

Journal of English for Academic and Spesific Purposes Volume 1 Number 1, June, 2018

This situation might raise speaking problems to learners that might bring learners feel difficult to develop their speaking skill and they might even become passive speakers. To solve this problem, EFL learners need to know more about Communication Strategies. By employing communication strategies in communication learners might solve their speaking problems. Further, using communication strategies learners might meet their communication goals (Dornyei, 1995). Related to communication strategies, this study is going to discuss on code switching strategies usage as one of the communication strategies which EFL learners might employ to improve their speaking skill. It includes the description of research methods, discussion of findings related to some related theories and research findings on the use of code switching strategies in communication and conclusion.

\section{METHOD}

This research applied a qualitative case study design. In a qualitative research in education, the researcher depends on the research participants. The researcher collects the data from the subjects in the form of words and he describes and analyzes these words based on themes (Creswell, 2002). Next, a case study is a detailed assessment of one setting, or a single subject, a single depository of documents, or one particular event (Merriam, 1988). In this research, I drew on two EFL learners as the subjects, subject1 and subject 2. These two EFL learners were selected as the subjects of the study due to their activeness in practicing speaking in the class and outside the class. In this study, I focused on finding their use of code switching strategies and the reason why those two EFL Learners apply those strategies in communication.

The data in this research were in the form of learners' verbal expressions. Susanto (2010) states that data refer to all information needed and are collected by the researcher as the basis to answer the research questions. In addition, Bogdan and Biklen (1992) assert that the data are the scrupulous information that shapes the basis of analysis. Data would cover all things that people are doing in the study. Thus all information about the subjects is very 
important in the research and they are needed to answer the research questions. In this research, learners' verbal expressions were got from the utterances expressed by the learners when they had conversation and discussions with their speaking partners. These learners' verbal expressions were recorded and then transcribed to produce transcribed data.

In this research, the data were collected through observation and indepth interview. In the observation, I acted as the non-participatory observer and I observed the subjects when they had conversations and the discussions with their speaking partners. During the observation, I recorded learners' utterances using a mini recorder and noted some code switches that they did throughout the conversation. Then, I interviewed them the reason why they employed code switching strategies in the conversation. Afterward, I transcribed the recorded data and discussed the transcribed data related to some related theories and research findings on the use of code switching strategies in communication.

\section{FINDINGS AND DISCUSSION}

From the analysis, it is found that Subject 1 used code switching strategy. It was known when he was speaking with one of his lecturers in faculty living room. The data indicated that the subject used code switching strategy in term of using the word medok (L1) when he wanted to explain about the way he spoke Javanese. He said: “... and / I I've never ee felt this medok in Makassar / so it is ee so different with my hometown //...". He did code switching strategy because he did not know the meaning of the word medok in English. Further, he did it because he wanted to gain the conversation goal in describing about the way he spoke Javanese. He stated: "I use the word medok in my speaking because I do not know the English of that word...I'm not a Javanese, so I've never heard about that word. Besides, I've not found from dictionary, especially in English dictionary (Cambridge, Oxford, etc) about the English of medok. 
JEASP

EaS10 Journal of English for Academic and Spesific Purposes Volume 1 Number 1, June, 2018

An important point to be noted here is that Subject 1used code switching strategies using the Javanese word medok during the conversation. It was done because he did not know the meaning the word medok in English. He found that by using code switching strategies he could continue his conversation. And he enjoyed to do it as far as his speaking partner understand him. The use of code switching strategy implies that Subject 1 has made an effort to improve his speaking skill by using code switching strategy during communication. It was done when he found difficulties in translating a Javanese word in English and using code switching strategies he could continue to express his ideas. Thus the use of code switching strategies as a part of communication strategies has helped Subject 1 to facilitate his learning speaking in term of handling his speaking problems due to her limited vocabularies. This can be known from the following quotation, Subject 1: "I think it is very useful for me to use those communication strategies since I am not a native speaker and I have limited vocabularies. Sometimes I forgot some words that made me hard to continue a conversation. But, the use of communication strategies helps me a lot to handle problems in speaking. Communication strategies can improve my speaking skill since some strategies help me find out a way to deliver a message." Thus, it might be concluded that the use of code switching strategy as a part of communication strategies is very useful for Subject 1 to handle his speaking problems that he faced during communication due to his limited vocabularies. In addition, the use of code switching strategies is acceptable to the listener as the listener gave positive response in term of nodding showing an understanding when Subject 1 changed his language from English into Javanese (using the word medok).

Next, Subject 2 also employed code switching strategy. It was known when he wanted to explain about being a musrif (an Arabic term for students' mentor). The data indicated that Subject 2 told that at first he hated being a musrif. But, when he found that a musrif is a person who likes to help students in their study he changed his ideas. Finally, he liked being a musrif and he even enrolled himself to be a musrif. This was one of his ways to ask for apology for hating a musrif. Thus, Subject 2 did 
JEASP

Journal of English for Academic and Spesific Purposes

Volume 1 Number 1, June, 2018

code switching strategy in term of employing the word musrif instead of using the word students' mentor. Then, Subject 2 applied another code switching strategy. It was found when Subject 2 used the word apa menebus to explain about his regret to hate the musrif. He said: "that I / I am wrong because musyrif is // someone that help us very much so // to ee / apa menebus $/ / /$ ?...”. From the statement above, it is found that Subject 2 did code switching strategies in term of using the word menebus (L1) when he was having conversation with his speaking partner. He did code switching because he did not know the meaning of the word menebus (L1) in English. Further, he did it due to continue his conversation. He stated: "I do not know the meaning of menebus (L1) in English and I use this word because I don't want to stop my conversation". The use of code switching strategy by Subject 2 indicates that Subject 2 has made an endeavor to improve his speaking skill by using code switching strategies (From L2 to L1) during communication. It was done when he found difficulties to express some words in English. By using code switching strategies changing some terms in L1 made him be able to continue expressing his ideas. The use of code switching strategies was acceptable to the listener because the listener gave a positive response by nodding his head. It happened when Subject 2 changed his language from English into Javanese (L2 to L1).

From the finding above, an important point to be noted is that Subject 1 and Subject 2 have some speaking problems due to their lack of vocabularies. Being lack of vocabularies has made Subject 1 and 2 feel difficult to develop their speaking skill. This condition has caused knowledge gaps for them in learning English especially in learning English speaking. The impact of this knowledge gaps might make them feel difficult to develop their speaking skill. Further, it is difficult for them to achieve fluency in speaking. Related to the knowledge gaps that happen to the learners due to their lack of vocabularies, Bialystok (1990:1) states that there are some gaps of knowledge of second language which might influent fluency. The forms of these gaps might be a word, a structure, a phrase, a tense marker or an idiom. Being lack of linguistic elements such as being lack of vocabularies might cause learners to have speaking problems. 
JEASP

Journal of English for Academic and Spesific Purposes Volume 1 Number 1, June, 2018

Afterward, to cope the problems of being lack of vocabularies in EFL learning which might influence learners' mastery in speaking, learners need to know about more about communication strategies. Related to the use of communication strategies learners might use to solve their communication problems due to their limited vocabularies, Ellis (1994) states that communication strategies are the process of how the learners use of the existing knowledge of the L2 to cope with communication difficulties. Commonly learners do not master every item of L2. They need certain strategies to compensate the gaps. In addition, Karimnia and Zade (2007) state that learners might face some problems in communication due to their limited or imperfect knowledge of rules and communication strategies can help them cope with these problems to reach their communication goals. Then, to solve learners' speaking problems due to the gaps of the second language knowledge that learners have in EFL learning, instead of knowing about communication strategies, learners need to improve their understanding about linguistic elements such as grammar understanding and vocabularies so that they might speak better and fluently (Syamsudin, 2016). Further, Nunan (1991:39) states that to be able to speak well, there are some linguistic elements that students should master such as grammar, vocabulary, intonation, pronunciation, stress, and the choice of language functions. Thus, mastering linguistic elements are very crucial in the process of EFL learning. Having sufficient knowledge about linguistic elements learners might handle the problems they face during the conversation.

Next, the study found that both learners, Subject 1 and Subject 2, have employed code switching to solve the knowledge gaps in term of having limited vocabularies strategies during the conversation. It was known when they employed L1, using the words menebus and medok, during the conversation. By using code switching strategies both learners have facilitated themselves to be free of linguistic insecurity. This might make them develop their speaking skill because learners might use the language which is comfortable for them in the conversation. Related to the use of code switching strategies to be out of linguistic insecurity, Burenhult (1999) states that linguistic insecurity might be eased using code switching strategies using the language which is most comfortable for the speaker. In addition, Hammink 
JEASP

EaS10 Journal of English for Academic and Spesific Purposes Volume 1 Number 1, June, 2018

(2000) states that learners might handle their speaking problems employing code switching using the more readily available lexical expression. Next, Navehebrahim \& Jamshidi (2013) state that using of code switching strategies during the conversation might lead learners feel comfortable and enjoy greater competence. So, learners might use code switching strategies when they have linguistic insecurity due to their lack of vocabularies. Using code switching strategies in term of employing L1 or using the language which is most comfortable for them, learners might feel comfortable and enjoy greater competence.

Subsequently, the study found that code switching strategies might facilitate learners to learn speaking. By employing code switching strategies in communication learners might develop their speaking skill. This might be known from their activeness in the conversation practicing speaking with their speaking partners employing code switching strategies to keep on their conversation to move on and further to gain their communication goals. Thus, the use of code switching strategies involving their L1 in the conversation has given positive impacts to the learners in term of building learners' self confidence to speak English. This further might impact learners to practice speaking more and more till they might achieve speaking proficiency. Related to the use of code switching strategies for developing speaking skill, Ellis (2008) stating that learners might use certain strategies for the sake of L2 development and proficient learners tend to use learning strategies more frequently and qualitatively in different ways. Next, Miharsani \& Mamaghani (2009) Explored code switching and Iranian EFL learners' oral proficiency found that code switching strategies as one of the communication strategies can have positive impacts on EFL Learners' oral proficiency. In this case, code switching strategy used in communication in EFL Learning might function as the productive learning strategy which can promote interaction between earner-teacher and learner-learner. Code switching strategies might be used to improve EFL learners' speaking skill.

In addition, the study found that the use of code switching strategies has facilitated learners to achieve speaking proficiency. This happened when learners keep on speaking with their speaking partners employing code switching strategies ignoring their speaking problems in term of finding difficult vocabularies in the 
JEASP

EaS Journal of English for Academic and Spesific Purposes Volume 1 Number 1, June, 2018

conversation. This consequently might bring learners to achieve fluency in speaking and further might bring learners to gain speaking proficiency. The finding of the study is in accordance to Anselmo \& Williams (2012) investigated code switching used by young children. Their finding indicated that code switching technique supports the acquisition of a second language for young learners. In this case, code switching strategy has helped learners gain acquisition in learning speaking.

Next, the study found that the use of code switching strategies in learning speaking might give some benefits to learners. Generally, using code switching strategies learners might handle their speaking problems because these strategies might arise learners' feeling comfortable and confidence to practice speaking. The use of code switching strategies might bring learners to have successful communication with their speaking partners. Further, using code switching strategies learners might develop their speaking skill. This is in line to Modupeola (2013) who states that there are some benefits of using code switching strategy by learners in communication such as by doing code switching strategy learners might have an opportunity for language development since it tolerates for effective transfer of ideas from the senders to the hearers. Next, the exposure to do code switching at the early stages of learning enables learners to gain effective and successful learning and step by step it might bring learners to be proficient speakers. In addition, the use of code switching in communication helps learners enjoy their learning due to their ability to comprehend the teacher input. The comprehensible input might bring learners to feel relax and become more comfortable to learn so that learners might be able to focus and participate in the classroom practice and activities successfully. These psychological aids bring learners to feel more relaxed and comfortable to learn English. In addition, Pollard (2002) states that learners who have the opportunity to code switch freely during the conversation might have fewer language barrier. This might bring them to transmit the information that they have learned to teachers or peers due to the language freedom of using code switching. On the contrary, learners who are not allowed to code switch, they often stopped themselves at the midsentence. It does not mean that they did not know the answer to a question, when perhaps they did know the answer but lack of the vocabulary in English. 
JEASP

Journal of English for Academic and Spesific Purposes Volume 1 Number 1, June, 2018

Further, the study found that both learners agreed that using code switching strategies as parts of communication strategies is believed to be able to help them solve their speaking problems in communication and using communication strategies hey might build mutual understanding with their interlocutors. This is relevant to Dornyei (1995) who states that communication strategies are the strategies that learners employ to handle their communication problems. In accordance to Dornyei's opinion, Bialystok (1990) states that using communication strategies learners might handle their linguistic problems and talk more comprehensibly. So, communication strategies, especially codes switching strategies as one means of communication are very crucial to be used in the process of learning speaking in EFL Learning. Communication strategies were important for the EFL learners to reach their communication goals. In addition, Ellis (1994) states that learners might use communication strategies to handle their communication problems due to their linguistic problems, So, learners might employ communication strategies to achieve their communication goals. Communication strategies might be used to handle learners' limitedness in interlanguage resources. In addition, the study found that both learners agreed that the use of communication strategies especially the use of code switching strategies might help them to build mutual understanding with the interlocutors. This mutual understanding had made them have more fluent conversation which might bring them to reach to communication goals. This is in line with Tarone (1980) stating that communication strategies are mutual attempts of two interlocutors to agree on a meaning when requisite meaning structures are not shared.

The results of the study indicated that code switching strategies usage in communication might assist EFL learners to learn speaking. By employing code switching strategies in conversation learners might solve their speaking problems due to their limited understanding on vocabularies. In addition, the use of code switching strategies might impact learners to have positive psychological conditions such as being comfortable, courageous and having self confidence so that they become more active to do more speaking practices with their speaking partners. This positive psychological condition has brought learners to be more motivated to practice 
JEASP

1FaSP Journal of English for Academic and Spesific Purposes Volume 1 Number 1, June, 2018

speaking. And motivation, either intrinsic or extrinsic motivation, has a big influence in learners' success to learn a language. Learners having strong intrinsic motivation know the advantages of learning a particular language and reminding learners about the jobs waiting for fluent language speakers might be an important motivation for learners. In addition, extrinsic motivation might be given through some rewards (Richards \& Renandya, 2007).

Next, having positive psychological conditions in the conversation might bring learners to able to put across their ideas to the interlocutors fluently. This might further bring learners to improve their speaking skill and to achieve speaking proficiency. Knowing the importance of code switching strategies in improving learners' speaking skill, it is necessary for the learners to know more about code switching strategies that they might employ in the their speaking practices. This might be done by giving learners some strategies training about the use of code switching strategies in the conversation which might impact learners to have better speaking performance. This is in line to cognitive psychology theory stating that strategies training on learners are effective in improving students' performance on problem-solving tasks (Brown et al. 1983 in O’Malley \& Chamot, 1990). In addition, beside knowing about code switching strategies which is a part of strategic competence including verbal and non verbal communication strategies to handle communication problems due to learners' insufficient competence, to improve learners' speaking skill, learners need to know more about some other aspects of communicative competence which consist of grammatical competence covering vocabulary, pronunciation, grammatical structures and word forms. Sociolinguistic competence consisting of sociocultural rules for using language appropriately and discourse rules for linking parts of a language text coherently and cohesively (Canale \& Swain, 1980 in O’Malley \& Chamot, 1990).

\section{CONCLUSIONS}

From the discussion above, it might be concluded that the use of code switching strategies in conversation in EFL learning might give some benefits for learners. For the most part, the use of code switching strategies in the conversation 


\section{JEASP}

FaSP Journal of English for Academic and Spesific Purposes Volume 1 Number 1, June, 2018

might bring learners to have positive psychological condition which might lead learners to be more motivated to practice speaking either with their friends or their teachers. This supplementary might affect learners to improve their speaking skill and finally to achieve their speaking proficiency. Thus, it is necessary to give learners some guidance about the use of code switching strategies in the conversation in EFL learning so that learners might be able to handle their speaking problems to improve their speaking performance.

\section{REFERENCES}

Anselmo, G. \& Williams, M. (2012). Does Code Switching Work for Young Children? A Case Study of English Language Learners. Proceeding of the National Conference on Undergraduate Research (NCUR) 2012. Weber State University, Ogden Utah.

Bialystok, E. (1990).Communication Strategies: A Psychological Analysis of SecondLanguage Use. London: Basil Blackwell.

Bogdan, R.C. and Biklen, S.K. (1992). Qualitative Research for Education: An Introduction to Theory and Methods. Boston: Allyn and Bacon.

Brown, D. H. (2007). Principles of Language Learning and Teaching. New Jersey: Prentice Hall

Burenhult, N. \& Mattsson. (1999). Code Switching in Second Language Teaching of French. Working Papers 47. 59-72.

Creswell, J.W. (2002). Qualitative Inquiry and Research Design. London: SAGE Publications.

Dornyei, Z. (1995). On the Teachability of Communication Strategies. TESOL Quarterly, (29),55-58.

Ellis, R. (1994). The Study of Second Language acquisition. Oxford: Oxford University Press.

Ellis, R. (2008). The Study of Second Language acquisition.2 Ed. Oxford: Oxford University Press.

Hammink, J.E. (2000). A Comparison of the Code Switching Behavior and Knowledge of Adults and Children. Texas: University of Texas. 


\section{JEASP}

Eas Journal of English for Academic and Spesific Purposes Volume 1 Number 1, June, 2018

Karimnia, A. \& Zade, S.S. (2007). Communication Strategies: English Language Departments in Iran. Iranian Journal of Language Studies (IJLS). (1), 287300.

Merriam, S.B. (1998). The Case Study Research in Education. San Francisco: JosseyBass.

Miles, M.B. \& Huberman, A.M. (1984). Qualitative Data Analysis. California: SAGE Publication, Inc.

Miles, M.B. \& Huberman, A.M. (1994). Qualitative Data Analysis. 2 Ed. London: SAGE Publication, Inc.

Mirhasani, A. \& Mamaghani, H.J. (2009). Code-Switching and Iranian EFL Learners' Oral Proficiency. Journal of Teaching English as a Foreign Language and Literature. 1(2), 21-31

Modupeola, O. R. (2013). Code-Switching as a Teaching Strategy: Implication for English language Teaching and Learning in a Multilingual Society. IOSR Journal of Humanities and Social Science (IOSR-JHSS). Vol. 14, (3) 9294.

Navehebrahim, M. \& Jamshidi, A. (2013). Learners Use of Code Switching in English as a Foreign Language Classroom. Australian Journal of Basic and applied Sciences, 7 (1): $186-190$.

Nunan, D. (1991). Language Teaching Methodology.A Textbook for Teachers. New York: Prentice Hall International, Ltd.

O’Malley, J.M. \& Chamot, A.U. (1990). Learning Strategies in Second Language Acquisition. USA: Cambridge University Press.

Pollard, S. (2002). The Benefit of Code Switching within a Bilingual Education Program. Illinois: Illinois Wesleyan University.

Richards, J.C. \& Renandya, W.A. (2007). Methodology in Language Teaching. USA: Cambridge University Press.

Susanto. (2010). KonsepPenelitian Tindakan Kelas dan Penerapannya. Surabaya: Lembaga Penerbitan FBS UNESA

Syamsudin. (2016). The Use of Non Linguistic Means Strategies as a SpeakingProblem Solving in EFL Learning. International Journal of English Language Education. Vol. 4, No. 2.

Tarone, E. (1980). Communication Strategies, foreigner talks and repair in interlanguage. Language Learning (30), 417-431. 